\title{
Review
}

\section{The renin-angiotensin system in clinical medicine}

\author{
J. Carlos Romero \\ S. W. Hoobler \\ Ann Arbor, Mich.
}

$\mathrm{T}$ he present review will describe some of the more recent developments in the clinical utilization of knowledge concerning renin and angiotensin acquired in the last two years. It is not intended to be all inclusive or to review information published prior to 1967 , by which time several excellent summaries of current knowledge in this field were published. ${ }^{1-7}$ Furthermore, the extensive developments in the methodology of renin and angiotensin assays will not be discussed, since the purpose is to present the clinician with the physiological background and recently accumulated knowledge concerning the renin-angiotensin system in clinical situations.

The well-known relationships are summarized in the following equations:

$$
\begin{aligned}
& \alpha \text {-globulin + Activators } \\
& \text { scibstrate } \longrightarrow \text { Angiotensin I } \\
& \text { (decapeptide) } \\
& \stackrel{\text { Converting enzyme }}{\longrightarrow} \text { Angiotensin II } \\
& \text { (octapeptide) }
\end{aligned}
$$

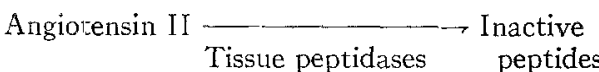

The first reaction is ordinarily considered to be the rate-limiting one. Angiotensin II is the significant product: It is a vasoconstrictor, evokes aldosterone secretion, and thus leads to sodium retention. It is rapidly destroyed in the capillary circulation by tissue angiotensinases. Since the $\alpha$-globulin substrate is usually in excess and converting enzyme is ubiquitous, renin is the significant precursor. It is secreted by the kidney apparently in response to a decreased tubular sodium load. Because of its large molecular size, it remains in circulating plasma for some time (half-life, 45 minutes after binephrectomy). ${ }^{8}$ It is measured by the amount of angiotensin it produces under suitable conditions of incubation. Since inhibitors or activators of the enzyme are almost certainly present in plasma, it should be stressed that assays for ronin include the effects of such coenzymes or even of modifications of substrate. Hence the term plasma renin-like activity (PRA) will be used in the discussion that follows.

The physiological role of renin has been the subject of much speculation. The original concept that its purpose was to regulate perfusion pressure to the kidney whose renal artery was obstructed has been replaced by the broader hy pothesis that it is the primary stimulus for maintenance of body sodium balance: The support for this theory cannot be:- détailed here, but it seems attractive to these reviewers since

From the Hypertension Research Unit, Department of Internal Medicine, University of Michigan Medical Center. Ann Arbor, Mich.

Reprint requesls lo: Dr. Hoobler, University Huspital, University of Michlgan Medical Center, Department of Internal Medicine, Ann Arbor, Mich. 48104. 
it explains well the two classical conditions in which PRA is increased: (1) when there is a decreased renal perfusion pressure, and (2) when there is a decreased delivery of sodium and water to the macula densa cell in the distal tubule. In the former instance (renal artery stenosis, systemic hypotension, afferent renal arteriolar vasoconstriction from blood loss, upright posture, or malignant hypertension), there is inevitably a decrease in filtration of sodium and water at the glomerulus and thereby a probable decrease in the amount of sodium delivered to the distal tubule where macula densa cells may serve as the sensing mechanism. Decreased sodium delivery to the distal tubules probably also occurs without an obvious change in renal hemodynamics during dietary salt restriction and in certain disease states associated with sodium retention. Decreased PRA is seen in contrary circumstances: increased renal perfusion pressure, expanded plasma volume, and salt loading.

PRA may also increase as a result of dircet hormonal or pharmacologic cffects perhaps altering the permeability of the macula densa cell to sodium (furosemide). There must likewise be a feedback control mechanism to reduce PRA. Although little is known, it does seem clear that angiotensin infusions reduce PRA. ${ }^{9}$

Renin-angiotensin in blood pressure regulation: inhibitors and activators. The many conditions in which renin is secreted in excess and in which blood pressure remains normal cast doubt on the direct role of renin in blood pressure regulation; if it is significant in the causation of essential or renovascular hypertension, an as yet unknown factor must coexist. Renin antibody infused intravenously will not lower blood pressure in the hypertensive animallo; the plasma level of renin in chronic Goldblatt hypertension is normal, ${ }^{11,12}$ and when it is found to be elevated in experimental hypertension, the explanation usually lies in a physiologic situation in which the kidney needs to retain salt and water..$^{13}$

It is entirely possible that the relation of renin to hypertension may be through the release of angiotensin at vascular receptors. Since this molypeptide is rapidly removed by tissue angiotensinases, its level in peripheral blood may not reflect its vasoconstrictor activity at the locus of the arteriole, just as circulating norepinephrine is an inadequale reflection of the sympathetic nerve release of norepinephrine at receptor sites. Activators or inhibitors of renal and endocrine origin may affect the rate of angiotensin production without changing the level of circulating renin. We have recently demonstrated that the rise in blood pressure occurring after ablation of a normal kidney in an animal with a unilateral renal artery clip is associated with a marked increase in the rate of angiotensin generation in vitro. ${ }^{14}$ Furthermore, such increased angiotensin generation and the concomitant enhanceb pressor response to renin seen after dinephrectomy is inhibited by normal renal medulla. ${ }^{15}$ Finally, in the experimental hypertensive animal a renin inhibitor has been described which when injected lowers the blood pressure to normal. ${ }^{16}$

After nephrectomy, angiotensin, presumably derived from a nonrenal source of renin or by the action of a like enzyme perhaps rendered more apparent by the absence of a renal inhibitor, reappears in blood. ${ }^{17}$ Uterine tissue and salivary gland have been shown to contain renin..$^{18-20}$ Arteries thennselves exhibit some renin-like activity. ${ }^{21}$

Some experimental observations concerning the mechanism of renin release. Although most of the experiments to be cited in this section were made prior to the period covered by the present review, some of the more pertinent observations will be discussed at this point.

The macula densa theory, that sodium delivery to the distal tubule is the controlling factor in renin release, now has wide acceptance but some discrepancies remain. It is probably not distal tubular sodium concentration but total sodium delivery which is the important signal. Micropuncture studies have indeed shown that distal tubular sodium concentration changes very slightly and unpredictably during maneuvers producing a reduction in renal artery perfusion pressure; however, the total sodium load presented to the distal tubular cell is always substantially reduced in these states. A further difficulty 
with acceptance of the macula densa theory concerns the response to furosemide. The increased tubular sodium delivery following administration of furosemide, occurring at the onset of diuresis and without change in total body sodium, has been shown to be associated with an increase in PRA. ${ }^{22}$ Vander ${ }^{6}$ has postulated that the macula densa cells may accumulate sodium internally in relation to the amount previously presented to them in the tubular lumen. The paradox which occurs during furosemide diuresis without change in salt balance, he suggests, is caused by the action of certain diuretics in reducing the permeability of the wall of the macula densa cell to this sodium influx. ${ }^{23}$

The assumption that the macula densa cell signals the juxtaglomerular (JG) cells to release renin has good theoretical support. The unusual orientation of the cytoplasmic constituents and the special permeability of the interface belween macula densa cell and the JG cell support this theory, ${ }^{1}$ and it is even possible that renin itself may also be elaborated in the macula densa cell. ${ }^{24}$

The baroreceptor hypothesis was based mainly on the experiments of Skinner, McCubbin, and Page, ${ }^{25}$ who have shown that renin release occurred with very slight reductions in mean arterial pressure (10 $\mathrm{mm} . \mathrm{Hg}$ ). The same authors observed that renin release is not dependent on pulse pressure, since a combination of aortic constriction and vagotomy (which virtually abolish the pulse pressure without changing the mean arterial pressure) fails to stimulate renin secretion. It would appear, at first glance, that this theory cannot explain the increased or decreased renin release observed in those circumstances that are not accompanied by the corresponding changes in renal arterial pressure, as, for example, during salt deprivation or sodium loading. ${ }^{26}$ However, changes in the renal arterial prcssure do not necessarily produce similar directional changes in the glomerular afferent arteriole or in its transmural pressure. Consequently, the variation of transmural pressure cannot be easily predicted or measured and it may be the controlling influence on $\mathrm{JG}$ cell activity. However, such a theory would not explain the intimate relation between these cells and the macula densa.

Another factor to be considered is the relation of the sympathetic nervous system ${ }^{27}$ and catecholamines ${ }^{28}$ to renin secretion. While many of their effects can bc explained by afferent renal arteriolar vasoconstriction and/or decreased sodium delivery to the distal tubule, some effects when catecholamines are applied directly to JG cells may require invoking an unknown mechanism of action. ${ }^{29}$

Chinical obsernations: 1968 to 1969. In Table I most of the publications devoted to renin measurements in the human being which appeared during 1968, and up to April, 1969, are summarized. They will be considered under the appropriate headings. The discussion which follows will attempt to relate these observations to the macula densa theory of renin release or inhibition.

Physiologic and pharmacologic stimuli. Agents which deplete plasma volume or decrease glomerular filtration rate (GFR) lead to a decrease in exposure of macula densa cells to sodium and hence excite renin release as a measure to preserve body sodium and total body fluids. Thus the effect of dietary sodium depletion is to elevate PRA. ${ }^{26,30}$ Thiazide diuretics act similarly, but after the steady state of salt depletion is reached, the amount of sodium passing through the renal tubules is equal to that in the diet. Accordingly, it is seen that chronic thiazide treatment is not associated with elevated plasma renin unless the patient also remains on a low sodium intake. ${ }^{31}$

Stimulation of sympathetic innervation to the kidney is known to produce afferent arteriolar vasoconstriction, decreased GFR, and a lessened sodium delivery to the distal tubule. Hence it is not surprising to learn that upright posture, ${ }^{28}$ apprehension, ${ }^{32}$ cold pressor stimulation, ${ }^{28}$ and catecholamine infusion ${ }^{28}$ cause high renin levels, while reserpine ${ }^{33}$ and clonidine hydrochloride (Catapres) ${ }^{34}$ decrease the blood levels of this enzyme. Hydralazine ${ }^{35}$ reduces blood pressure and acutely increases renal blood flow but does not increase GFR. Thus distal tubular sodium delivery may not be elevated. In any event this drug, 
Table I. Recent reporis on the renin-angiotensin system in various conditions in man ${ }^{*}$

\begin{tabular}{|c|c|c|c|}
\hline Condition & $P R A$ & Remarks & Reference \\
\hline \multicolumn{4}{|l|}{ Physiologic } \\
\hline $\mathrm{Na}$ depletion & + & $\ldots$ & 26,30 \\
\hline Thiazide, short-term & + & - & 31 \\
\hline long-term & 0 & - & 31 \\
\hline long-term & + & Added sodium restriction & 31 \\
\hline Cold pressor stimulation & + & - & 28 \\
\hline Upright posture & + & - & 28 \\
\hline \multicolumn{4}{|l|}{ Pharmacologic } \\
\hline Catecholamines & + & - & 28 \\
\hline Reserpine & - & - & 33 \\
\hline Clonidine $\mathrm{HCl}$ (Catapres) & - & -.. & 34 \\
\hline Hydralazine & + & - & 35 \\
\hline Furosemide & + & - & 22 \\
\hline Oral contraceptives & $0,+$ & Also increases renin substrate & 38 \\
\hline Sodium nitroprusside & + & - & 36 \\
\hline \multicolumn{4}{|l|}{ Pregnancy } \\
\hline Normal & + & -- & 39,40 \\
\hline Toxemic & + & Less than nommal increase seen & 40 \\
\hline \multicolumn{4}{|l|}{ Renal disease } \\
\hline Glomerulonephritis & 0 & Canine experimental & 44 \\
\hline Glomerulonephritis & 0 & Human nephritis & 45 \\
\hline Nephrosis & + & - & 45 \\
\hline Binephrectomy & - & - & 17,46 \\
\hline Transplant & 0 & Normal response to stimuli & 47,48 \\
\hline Obstructive uropathy with hypertension & + & - & 49 \\
\hline \multicolumn{4}{|l|}{ Hyperiension } \\
\hline \multirow[t]{2}{*}{ Renovascular } & \pm & -.. & $46,50-52$ \\
\hline & + & $\begin{array}{l}\text { Renal vein difference } \\
\text { significant }\end{array}$ & $46,53-57$ \\
\hline \multirow[t]{2}{*}{ Essential } & -.0 & $\begin{array}{l}\text { Response to stimuli sluggish } \\
\text { in } 25 \% \text { of cases, }\end{array}$ & \\
\hline & & especially in Negro & 59,60 \\
\hline Malignant & + & - & 46,52 \\
\hline Coarctation & 0 & - & 61 \\
\hline \multicolumn{4}{|l|}{ Hypolension } \\
\hline Postural & - & No rise with posture & 28 \\
\hline \multicolumn{4}{|l|}{ Endocrine diseases } \\
\hline Primary aldosteronism & . & $\ldots$ & 62 \\
\hline Licorice hypertension & - & - & 63 \\
\hline Bartter's syndrome & + & -..- & 64 \\
\hline "Pseudoaldosteronism" & - & $\ldots$ & 65 \\
\hline & + & $\cdots$ & 66 \\
\hline \multirow[t]{2}{*}{ Congenital adrenal hyperplasia } & + & Aldosterone secretion decreased & 67,69 \\
\hline & - & $\begin{array}{l}\text { DOC formed by lack of } \\
\text { 11-hydroxylase }\end{array}$ & 69 \\
\hline Miscellaneous diseases & & & \\
\hline Cirrhosis with edema & + & $\ldots .$. & 45 \\
\hline
\end{tabular}

PRA: $+=$ increased $;-z$ decreased; $0=$ no change.

DOC $=$ desoxycorticosterone.

*Drawn in most part from the medical literature, 1968 to 1969. 
like sodium nitroprusside $e^{36}$ which also lowers systemic blood pressure, increases renin release.

Certain compounds have effects on plasma renin which are as yet poorly explained: Furosemide ${ }^{22}$ appears to act directly, perhaps altering the permeability of the macula densa cell to sodium; adrenal cortical substances ${ }^{37}$ and oral contraceptives $^{38}$ raise "substrate" levels, but their influence on PRA results in no change or a slight increase ${ }^{38}$; the results may turn out to be due to the appearance of an activator of the renin-angiotensin reaction discussed in an earlier portion of this review, and this is almost certainly the explanation of the situation after nephrectomy in the experimental animal. ${ }^{15}$

Pregnancy. Pregnancy has assumed special interest. PRA rises, ${ }^{39,40}$ but less so in toxemia. ${ }^{40}$ The amniotic fluid and the chorion also contain renin-like activity. ${ }^{41,42}$ The high PRA levels persist after deliver $y^{39}$; hence the excess enzyme is not of fetal origin but is probably derived from the hypertrophied uterus. In this connection it is interesting that females but not males exhibit measurable renin activity after nephrectomy. ${ }^{17}$ Thus the uterus appears to provide a nonrenal source for renin in woman. PRA responds to the usual stimulation ${ }^{43}$ in pregnancy.

Renal diseases. The variable findings in renal diseases are probably related to the tubular sodium load obtained in these conditions. In chronic glomerulonephritis ${ }^{45}$ where this is presumably normal, PRA is not elevated, and it varies in nephrosis depending on the state of edema; PRA is elevated when sodium is being retained and falls to normal after diuresis. ${ }^{45}$ In the anephric individual PRA falls ${ }^{17,46}$ but rises again with transplantation and responds normally to physiologic stimuli (thus presumably excluding nervous connections as the intermediary for this influence). ${ }^{47,48}$ Obstructive uropathy has been little studied, but in one case with hypertension subsequently cured by surgery, PRA was elevated in the renal vein blood of the obstructed kidney. ${ }^{49}$

Hypertension. The situation in renovascular hypertension has been widely studied. Systemic PRA has not been shown to be constantly elevated in cases of renovascular hypertension; however, in the majority of cases the peripheral samples are above normal,46,50 52 particularly after appropriate stimulation..$^{52}$ Perhaps the degree to which one or both kidneys is deprived of sodium flux at the level of the macula densa determines this variability. The extensive literature on this subject prior to the review period should be consulted. ${ }^{1-7}$ The recent review by Del Greco and co-authors $\mathrm{s}^{50}$ is particularly helpful in understanding this important but difficult topic. The difference in renin concentration from the renal veins is agreed to be diagnostic of a significant unilateral renal artery stenosis. ${ }^{* 4,53-57}$ This test is at least as reliable as the split function tests previously used..$^{57}$ A high renal vein concentration alone, not accompanied by an adequate renal blood flow, may account in some cases for false positive results. If systemic or vena caval samples taken from above the renal veins are high, this supports the probability of a high secretion rate and therefore of a potentially curable lesion. ${ }^{58}$

Patients with essential hypertension by contrast show in some cases a reduced PRA possibly because in this condition there is a reduced tubular sodiun reabsorption and therefore an increased sodium load to the macula densa. The response to stimulation is sluggish, and approximately 25 per cent of hypertensive patients with normal plasma volumes and normal aldo sterone excretion have a subnormal rise in PRA after stimulation..$^{59,60}$ In coarctation PRA is normal. ${ }^{61}$

Endocrine disorders. As we have mentioned, numerous endocrine secretions affect the renin-angiotensinogen reaction rate which may be reflected in an apparent increase in PRA. ${ }^{37,38}$ In primary aldosteronism there is an increased extracellular fluid volume and consequently a low level of PRA is seen. ${ }^{62}$ The same applies to licorice hypertension, ${ }^{63}$ the clinical analogue of desoxycorticosterone acetate

*In our experience and in that of Hunt and associates, ${ }^{56}$ the differences are accentuated by prior postural and sodiumdepleting stimuli. The differences are rapidly accentuated on assuming the upright posture but may be obscured by reassuming recumbency. 56 
hypertension in which the resting PRA is also low. In Bartter's syndrome ${ }^{64}$ of $\mathrm{JG}$ cell hyperplasia high renin levels are the result of autonomously high secretion rates. In a curious hypertensive condition described by Laragh and colleagues, ${ }^{65}$ low PRA is associated with high aldosterone secretion, but the blood pressure does not decline following adrenalectomy and no adrenal adenomas were found. In pheochromocytoma, ${ }^{66}$ PRA is elevated, probably through the intervention of the sympathomimetic secretions on renal blood flow.

Congenital adrenal hyperplasia (CAH) is a disorder of adrenal steroid binsynthesis. The defect in steroid synthesis has been shown to be due to a block of 21-hydroxylation. In the salt-losing form of the disease there is a good deal of evidence indicating a diminished synthesis of aldosterone. Consequently, approximately 30 per cent of individuals with $\mathrm{CAH}$ are unable to retain sodium and frequently develop some dehydration. Godard and co-workers ${ }^{67}$ measured PRA and aldosterone secretion rates in 7 patients ranging from 5 months to 12 years of age. They found a distinct increase of PRA in 60 per cent of the cases while on a liberal salt intake. Salt restriction produced a marked increase in PRA but a less than normal increase in aldosterone secretion. They concluded that, at least in the salt-losing form of the condition, there was a diminished synthesis of aldosterone and perhaps also an angiotensin-induced natriuresis. In this condition, compensatory hypertrophy of the JG cells has been found by Cara and Gardner. ${ }^{68}$

Imai and associates ${ }^{\theta \theta}$ obtained similar results in two patients with the salt-losing form of congenital virilizing adrenal hyperplasia. In one case of the hypertensive form of the disease, where there is deficiency of 11-hydroxylase production which leads to formation of desoxycorticosterone and to sodium retention, PRA was reported to be depressed.

\section{Conclusions}

The clinical data are, in general, consistent with the theory that renin release varies inversely with the tubular sodium load. Yany apparent winical paradoxes are explained when the intimate changes in renal sodium handling under diverse physiologic, pharmacologic, and disease states are related to the effect on tubular sodium delivery. Some discrepancies remain which may be related to less understood influences on the macula densa cell.

Subjects for fruitful clinical research would include studies of the effects of inhibitors and activators on the renin-angiotensin system and an explanation of the Low level and sluggish response of renin seen in some subjects with essential hypertension.

\section{REFERENCES}

1. Page, I. H., and McCubbin, J. W., editors: Renal hypertension, Chicago, 1967, Ycar Book Medical Publishers,.

2. Brown, J. J., Davies, D. L., Lever, A. F., and Robertson, J. I. S.: Renin and angiotensin. A survey of some aspects, Postgrad. Med. J. 42:153, 1966

3. Peart, W. S.: The renin angiotensin system, Pharmacol. Rev. 17:143, 1965.

4. Peart, W. S.: The functions for renin and angiotensin, Recent Progr. Hormone Res. 21:73, 1965.

5. Gross, F., Brunner, H., and Ziegler, M.: Renin-angiotensin system, aldosterone and sodium balance, Recent Progr. Hormone Res. $21: 119,1965$.

6. Vander, A.: Control of renin telease, Physiol. Rev. 47:359, 1967.

7. Brown, J. J., Lever, A. F., and Robertson, J. I. S.: Plasma renin concentration in human hypertension, AMER. HEART J. 74:413, 1967.

8. Devaux, C., Menard, J., Alexandre, J. M., Idatte, J. M., Brisset, J. M., Beauve-Mery, P., Fendler, J. P., Safar, M., Weil, B., Meyer, P., and Milliez, P.; Speed of disappearance of plasma renin activity and variations in plasma angiotensin after bilateral nephrectomy in two hypertensive patients, J. Urol. Nephrol. 74:341, 1968.

9. Vander, A. J., and Geelhoed, G. W.: Inhibition of renin secretion by angiotensin, Proc. Soc. Exp. Biol. Med. 120:399, 1965.

10. Weiser, R. A., Johnson, A. G., and Hoobler, S. W.: The effect of antirenin on the blood pressure of the fat with experimental renal hypertension, Lab. Invest, 20:326, 1969.

11. Fasciolo, J. C., DeVito, E., Romero, J. C., and Cuechi, J. N.: The renin content of the blood of humans and dogs under several conditions, Canad. Med. Ass. J. 90:206, 1964.

12. Blair-West, J. R., Coghlan, J. P., Denton, D. A., Orchard, E., Scoggins, B. A., and Wright, R. D.: Renin-angiotensin-aldosterone system and sodium balance in experimental renal hypertension, Endocrinology 83:1199, 1968. 
13. Davis, J. O., Howards, S. S., Johnston, C. I., and Wright, F. S.: Renin, sodium-retaining and sodium-excreting hormones and experimental renal hypertension, Circ. Res. 21 (Suppl. 2): $167,1967$.

14. Lazar, J. D., Romero, J. C., and Hoobler, S. W.: Correlation of the initial velocity of the renin angiotensinogen reaction with the evolution of experimental renal hypertension, Fed. Proc. $28: 329,1969$. (Abst.)

15. Romero, J. C., Lazar, J., Elkins, M., and Hoobler, S.: Effect of nephrectomy and the readministration of renomedullary extracts on the vascular response to renin and the kinetics of the renin-angiotensinogen reaction, Circulation 39-40 (Suppl. 3):173, 1969.

16. Sen, S., Smeby, R., and Bumpus, F. M.: Plasma renin activity in hypertensive rats after treatment with renin preinhibitor, Amer. J. Physiol. 216:499, 1969.

17. Capelli, J. P., Wesson, L. G., Aponte, G. E., Faraldo, C., and Jaffe, E.: Characterization and source of a renin-like enzyme in anephric humans, J. Clin. Endocr. 28:221, 1968.

18. Gross, F., Schaechtelin, G., Ziegler, M., and Berger, M.: A renin-like substance in the placenta and uterus of the rabbit, Lancet 1:914, 1964.

19. Bing, J., and Faarup, P.: Location and site of formation of extrarenal renin, in Milliez, P., and Tcherdakoff, editors: L'Hypertension arterielle, L'Expansion Scientifique, Paris, 1966.

20. Anderson, R. C., Herbert, P. N., and Mulrow, P. J.: A comparison of properties of renin obtained from the kidney and uterus of the rabbit, Amer. J. Physiol. 215:774, 1968.

21. Gould, A. B., Skeggs, L. T., and Kahn, J. R.: The presence of renin activity in blood vessel walls, J. Exp. Med. 119:389, 1964.

22. Meyer, P., Menard, J., Papanirolan, N., Alexandre, J. M., Devaux, C., and Milliez, P.: Mechanism of renin release following furosemide diuresis in rabbit, Amer. J. Physiol. 215:908, 1968.

23. Vander, A. J., and Carlson, J.: Mechanism of the effects of furosemide on renin secretion in anesthetized dog, Circ. Res. 25:145, 1969.

24. Warren, B., Johnson, A. G., and Hoobler, S. W.: Characterization of the renin-antirenin system, J. Exp. Med. 123:1109, 1966.

25. Skinner, S. L., McCubbin, J. W., and Page, I. H.: Control of the renin secretion, Circ. Res. 15:64, 1964 .

26. Romero, J. C., Staneloni, R. J., Dufau, M. L., Dohmen, R., Binia, A., Kliman, B., and Fasciolo, J. C.: Changes in fluid compartments, renal hemodynamics, plasma renin and aldosterone secretion induced by low sodium intake, Metabolism $17: 10,1968$.

27. Bunag, R. D., Page, I. H., and McCubbin J. W.: Neural stimulation of release of renin, Circ. Res. 19:851, 1966.

28. Gordon, R. D., Kuchel, O., Liddle, G. W., and Island, D. P.: Role of the sympathetic nervous system in regulating renin and aldo- sterone production in man, J. Clin. Invest. 46:599, 1967.

29. Michelakis, A. M., Caudle, J., and Liddle, G. W.: In vitro stimulation of renin production by epinephrine, norepinephrine and cyclic AMP, Proc. Soc. Exp. Biol. Med. 130:748, 1969.

30. Weinberger, M. H., Dowdy, A. J., Nokes, G. W., and Luetscher, J. A.: Plasma renin activity and aldosterone secretion in hypertensive patients during high and low sodium intake and administration of diuretic, J. Clin. Endocr. 28:359, 1968.

31. Bourgoigne, J. J., Catanzaro, F. J., and Perry, H. M.: Renin-angiotensin-aldosterone during chronic thiazide therapy of benign hypertension, Circulation 37:27, 1968.

32. Hoobler, S. W.: Unpublished data.

33. Slotkoff, L. M., Eisner, G. M., and Lilienfield, L. S.: Effect of autonomic nervous system on renin secretion, Fed. Proc. 28:715, 1969. (Abst.)

34. Dobrzinsky, S., Christlieb, A. R., Forrester, J., and Hickler, R. B.: Metabolic effects of catapres. Second Symposium on Catapres, September 18-19, New York, 1968, Geigy Pharmaceuticals, p. 207.

35. Ueda, H., Yagi, S., and Kaneko, Y.: Hydralazine and plasma renin activity, Arch. Intern. Med. 122:387, 1968.

36. Kaneko, Y., Ikeda, T., and Ueda, H.: Renin release during acute reduction of arterial pressure in normotensive subjects and patients with renovascular hypertension, J. Clin. Invest. 46:705, 1967.

37. Helmer, O. M.: Renin activity in blood from patients with hypertension, Canad. Med. Ass. T. 90:221, 1964

38. Newton, M. A., Sealey, J. E., Ledingham, J. G. G., and Laragh, J. H.: High blood pressure and oral contraceptives. Changes in plasma renin and renin substrate and in aldosterone excretion, Amer. J. Obstet. Gynec, 101:1037, 1968.

39. Geelhoed, G. W., and Vander, A. J.: Plasma renin activities during pregnancy and parturition, J. Clin. Endocr. 28:412, 1968.

40. Gordon, R. D., Parsons, S., and Symonds, E. M.: A prospective study of plasma-renin activity in normal and toxemic pregnancy, Lancet 1:347, 1969.

41. Skinner, S. L., Lumbers, E. R., and Symonds, E. M.: Renin concentration in human fetal and maternal tissues, Amer. J. Obstet. Gynec. 101:529, 1968.

42. Symonds, E. M., Stanley, M. A., and Skinner, S. L.: Production of renin by in vitro culture of human chorion and uterine muscle, Nature 2I7:1152, 1968 .

43. Boonshaft, B., O'Connell, J. M. B., Hayes, J. M., and Schreiner, G. E.: Serum renin activity during normal pregnancy. Effect of alterations of posture and sodium intake, J. Clin. Endocr. 28:1641, 1968.

44. Fukuda, M., Greene, J. A., and Vander, A. J.: Plasma renin activity during development of 
experimental antiserum glomerular nephritis, J. Lab. Clin. Med. 71:148, 1968.

45. Imai, M., and Sokabe, H.: Plasma renin and angiotensinogen levels in pathological states associated with edema, Arch. Dis. Child. 43:475, 1968 .

46. Verniory, A., Cuykens, J. J., Cremer, M, Lotteau, B., and Toussaint, C.: La renine dans l'hypertension renale humaine et experimentale, Path. Biol. 16:583, 1968.

47. Blaufox, M. D., Lewis, E. J., Jagger, P., Lauler, D., Hickler, R., and Merrill, J. P.: Physiologic responses of the transplanted human kidney: sodium regulation and renin secretion, New Eng. J. Med. 280:62, 1969.

48. Greene, J. A., Vander, A. J., and Kowalczyk, R. S.: Plasma renin activity and aldosterone excretion after renal homotransplantation, J. Lab. Clin. Med. 71:586, 1968.

49. BeIman, A. B., Kroop, K. A., and Simon, N.: Renal-pressor hypertension secondary to unilateral hydronephrosis, New Eng. J. Med. 278:1133, 1968.

50. Del Greco, F., Simon, N. M., Goodman, B. S., and Roguska, J.: Plasma renin activity and secondary hyperaldosteronism, Medicine 46: $475,1967$.

51. Gunnells, J. C., Grim, C. E., Robinson, R. R., and Wildermann, B. S.: Plasma renin activity in healthy subjects and patients with hypertension, Arch. Intern. Med. 119:232, 1967.

52. Weidmann, P., Enders, P., and Siegenthaler, W.: Plasma renin activity and angiotensin pressor dose in hypertension. Correlation and diagnostic implications, Brit. Med. J. 3:154, 1968.

53. Fitz, A.: Renal venous renin determinations in the diagnosis of surgically correctable hypertension, Circulation 36:942, 1967.

54. Woods, J. W., and Michelakis, A. M.: Renal vein renin in renovascular hypertension, Arch. Intern. Med. 122:392, 1968.

55. Hunt, J. C., Strong, C. G., Sheps, S. G., and Bernatz, P. E.: Diagnosis and management of renovascular hypertension, Amer. J. Cardiol. 23:434, 1969.

56. Michelakis, A. M., Woods, J. W., Liddle, G. W., and Klatte, E. C.: A predictable error in use of renal vein renin in diagnosing hypertension, Arch. Intern. Med. 123:359, 1969.

57. Cerny, J. C., Hoobler, S. W., Macal, O., Bookstein, J. J., Hall, J. W., and Skeel, D. A.: Split renal function studies versus renal vein renins: A comparison in diagnosis and treat- ment in renal vascular hypertension, I. Urol. 102:529, 1969 .

58. Meyer, P., Ecoiffier, J., Alexandre, J. M., Devaux, C., Guize, L., Menard, J., Biron, P. and Milliez, P.: Prognostic value of plasma renin activity in renovascular hypertension, Circulation 36:570, 1967.

59. Fasola, A. F., Martz, B. L., and Helmer, O. M.: Renin activity during supine exercise in normotensives and hypertensives, J. Appl. Physiol. 21:1709, 1966.

60. Creditor, M. C., and Loschky, U. K.: Incidence of suppressed renin activity and of normokalemic primary aldosteronism in hypertensive Negro patients, Circulation 37:1027. 1968.

61. Pickens, P. T.: Relation of plasma renin to blood pressure in a patient with coarctation, Brit. Heart J. 29:135, 1967,

62. Brown, J. J., Fraser, R., Lever, A. G., and Robertson, J. I. S.: Potassium and the concentration of plasma renin during primary hyperaldosteronism, Path. Biol. 16:555, 1968.

63. Conn, J. W., Rovner, D. R., and Cohen, E. L.: Licorice-induced pseudoaldosteronism, hypertension, hypokalemia, aldosteronopenia and suppressed plasma renin activity, J.A.M.A. 205:492, 1968.

64. Cannon, P. J., Leeming, J. M., Sommers, S. C., Winters, R. W., and Laragh, J. H.: Juxtaglomerular cell hyperplasia and secondary hyperaldosteronism (Bartter's syndrome): An evalitation of the pathophysiology, Medicine 47:107, 1968.

65. Laragh, J. H., Ledingham, J. G. G., and Sommers, S. C.: Secondary aldosteronism and reduced plasma renin in hypertensive disease, Trans. Ass. Amer. Phys. 80:168, 1967.

66. Maebashi, M., Miura, Y., Yoshinhga, K., and Sato, L.: Plasma renin activity in pheochromocytoma, Jap. Circ. J. 82:1427, 1968.

67. Godard, C., Riondel, A. M., Veyrat, R., Megevand, A., and Muller, A. F.: Plasma renin activity and aldosterone secretion in congenital adrenal hyperplasia, Pediatrics 41: $883,1968$.

68. Cara, J., and Gardner, L. I.: The juxtaglomerular cells of the kidney and the zona glomerulosa of the adrenal cortex in the sodium losing and the hypertensive forms of virilizing adrenal hyperplasia, Pediatrics 32:825, 1963.

69. Imai, M., Igarashi, Y., and Sokabe, H.: Plasma renin activity in congenital virilizing adrcnal hyperplasia, Pediatrics 41:897, 1968. 